\title{
Pull Factors Affecting The Jobseekers Decision to Do Urbanization
}

\author{
Syamsul Amar', Ariusni², Alpon Satrianto ${ }^{3}$ \\ ${ }^{1}$ Universitas Negeri Padang, Padang and Indonesia, syamsul_amar3@yahoo.com \\ ${ }^{2}$ Universitas Negeri Padang, Padang and Indonesia, ariusni.fe.unp@gmail.com \\ ${ }^{3}$ Universitas Negeri Padang, Padang and Indonesia, alpon.unp@gmail.com
}

\begin{abstract}
The study aims to analyze the effects of pull factors affecting the decision of prospective job seekers to do urbanization to Padang and Pekanbaru. These factors consist of: economic infrastructure, educational facilities, medical facilities, employment opportunity, security level, and wage rate as independent variables. The population of the study was the prospective jobseekers represented by the students of Faculty of Economics, State University of Padang which were currently in the last semester (8th semester) amounted to 441 people. The sampling was performed by using Slovin formula. Based on the formula, a total sample of 210 people was obtained. The data were collected using an instrument directly addressed to the respondents. The analysis technique used the Logistic Regression Model. The economic infrastructure significantly affects the decision of jobseekers to do urbanization to both Padang and Pekanbaru. However, the opportunities of prospective jobseekers to do urbanization to Pekanbaru tend to be higher than to Padang. Educational facilities have a significant effect on the decision making of prospective job seekers to do urbanization, but the opportunity of prospective jobseeker to do urbanization to Padang tend to be higher compared to Pekanbaru. Health facilities significantly affect the decision of prospective job seekers do urbanization, but the trend of job seekers to do urbanization to Pekanbaru tends to be higher than to Padang. Employment opportunity variable becomes a significant consideration for prospective job seekers to do urbanization in determining the decisions, but the opportunity of prospective job seekers to do urbanization to Pekanbaru tends to be higher than to Padang. Two variables differentiate the job seekers to do urbanization to Padang and Pekanbaru. Those variables are the security level and the wage rate. Prospective job seekers tend to decide to do urbanization to Padang with the consideration of a higher level of security, while others move to Pekanbaru with the consideration of higher wage rate than to Padang.
\end{abstract}

Keywords: urbanization, economic infrastructure, health facilities, educational facilities.

\section{Introduction}

The industrial revolution in the West is the beginning of urban industries development which plays a role in absorbing labor, increasing economic growth and urban society welfare (Behera and Dash, 2017) (Cobbinah, 2015) (Wongboonsin, 2016) (McGranahan, 2009) (Jhingan, 2003). Urban industrialization is one of the pull factors of migration from rural to urban areas, although it is quite a dilemma in the process of urban development (Suckall, 2015) (Turok, 2013) (Bao, 2012) (Arouri, 2017) (Henderson, 2016). This phenomenon has occurred in developing countries, for example: in Asia, Africa and Latin America as part of the evolutionary process of urban development (Lian, 2014) (Liddle, 2014) (Miao, 2016). On the other hand, Isard (cit Todaro: 2005) explains the close relationship between urbanization and the development and urbanization for the agglomeration economies as the central force of economic growth in urban areas. In this age of digital, job search will be very easy to find job opportunities so that in the future will be able to encourage the high interest of job seekers. 
The high interest of job seekers will certainly have an impact on the urbanization of job seekers (Hariyono, 2007) (Curtis, 2015) (Wongboonsin, 2016) (Allen, 2002) (Buhaug, 2013).

Padang as the capital of West Sumatra province and Pekanbaru as the capital of Riau province have a larger population than other cities ineach provinces. Population of Padang is the highest compared to the 17 districts and six other cities in West Sumatra Province. In 2013 the population of Padang was as many as 876,670 then rose steadily into 899,561 in 2014 or with a growth rate of $2.6 \%$ (BPS: 2015). Due to the rapid population growth, the total population of Padang is the highest in West Sumatra Province with a population of 902,413 people in 2015. Meanwhile Pekanbaru also has a denser population than other regions in the Riau Province. Therefore, the city must anticipate the problems due to population density, so that a dense population will not be an obstacle in the development of the city as the issues of major problem in developing countries. A dense population implication will bring a lot of social, economic, security, political and environmental problems.

In addition to natural population growth, migration is one of the demographic components that affects the number and structure of the population in a region or a country. Migration is defined as the movement of people from one place to another within a certain period; it is a modern demographic phenomenon that is hardly to be denied by urban development. The migration flow is caused by push factors in the origin area and pull factors in the destination area; physical, social, economic, and cultural factors. In addition to the push factors, urban attraction such as multifaceted infrastructures and employment as well as security are the pull factors for people to migrate to Padang.

The same thing occurred in Pekanbaru, where the population of the city was 958,352. On the other hand the least number of populations was in Dumai. Riau Province with was only about 268,022 people in 2012. Even in 2014, the population of Pekanbaru exceeded one million. Pekan Baru is the capital of Riau Province with the largest population, compared to 10 districtsand cities in Riau Province. Based on a survey conducted by the University of Indonesia in 2013 on cities in Indonesia that serve as an investment destination in Indonesia, at that time Pekanbaru was as the first investment destination. It was inseparable from the existing real conditions such as, security guaranteed and services and adequate infrastructure. Along with the increasing investment flow to Pekanbaru, it provided considerable employment opportunities for job seekers. Moreover, it was strengthened by the effort employed by the Government of Pekanbaru to further enhance the appeal for the investors to invest in this city, with the increasing in the quality of four basic infrastructures, such as the road network, public transport, drinking water, electricity and telecommunications in order to spur economic growth and development of the city as fast as possible. For the construction of road infrastructure, from 2012 until 2013,the Pekanbaru government through the Department of Highways and Water Resources built over $129 \mathrm{~km}$, consisting of the increase in the quality of roads, construction of sidewalks and bridge widening. For the road construction in 2015, the government also undertook the construction of outer ring road in order to open up new access for the development of cities toward the Tenayan Raya Subdistrict. Increasing quantity and quality of the infrastructure will provide facilities to support the mobilization of goods and services performed by the investor.

In the last five years Padang has been experiencing significant economic growth with an average increase of $0.20 \%$ per year since 2011. The cause of the economic growth of Padang is an increase in the infrastructure such as Teluk Bayur port and Minangkabau Airport activity and thus the employment opportunity in Padang is very high. It contributes to an increase in the number of population in urban areas. The population living in urban areas than in rural areas is very high in each region in the province of West Sumatra. The population of Padang wasapproaching one million in the last three years from 2013 to 2015. Meanwhile, the people living in the rural areawere very few in number, only 9,024 people in 2015. Rapid population growth can seriously constrain local governments'ability to provide basic services, including employment, housing, electricity, water, 
sanitation, enforcement of law and order, and development of social capital, thus greatly affecting the quality of life of the citizens. Violence or inconvenience would arise in the event of excessive urbanization so that the labor market and the economy is unable to follow urban population growth (Buhaug \& Urdal, 2013).

On one hand, migration is a sign that the process of urban growth is running, but on the other hand, migration can lead to various problems and challenges to development activities in urban areas, due to the high migration which threatens the continuation of the development process in urban areas because of the huge budget must be provided by the city to provide services to its citizens. Pekanbaru is the city with high attraction for immigrants from all over Indonesia.Regarding the dynamics of demography, Pekanbaru since 2010 has made this city as the third most populous in Sumatra following Medan and Palembang and as the number of migrants from various ethnic groups including: Minang, Chinese, Batak and Malay who come to this city. Actually, increasing urbanization flow began by the expansion of Pekanbaru in the 1960s. The availability of large employment opportunities is not only caused by domestic investors who invest in this area, but also quite a number of foreign investors operating in this area. On the other hand, Pekanbaru has relatively high provincial minimum wage rate (UMP) compared to other regions in West Sumatra. In 2015, the provincial minimum wage for Pekanbaru was IDR1.925.000, while Padang was only IDR1.615.000 in the same year.

\section{Methods}

The research population was jobseekers represented by the students of the Faculty of Economics at the State University of Padang who are currently in the last semester (semester VIII) with a total of 441 people. The population was spread on four study programs: Study Program of Economic Education, Economic Development, Management and Accounting. The sampling technique was conducted using a Proportional Random Sampling by Slovin formula. Based on the formula, a total sample of 210 people was obtained and the amount is divided into each study program proportionately. The details were as follows: 42 people from Study Program of Economic Education, 50 people from study Program of Economic Development, 64 people from Program Study of Management and Study Program of Accounting of 54 people. The data used were primary data and data sources were the jobseekers presented by the students of the Faculty of Economics of State University of Padang. The data collecting used questionnaires. The instrument consisted of questions related to the variables and every independent variable presented in questions with odd number in total. The independent variables consisted of: economic infrastructure, educational facilities, medical facilities, employment, security level, wage rate and decisions to do urbanization as outcome variables. The measurement of outcome variable was carried out by dichotomy, i.e score $=1$ for respondents who made decisions to do urbanization and score $=0$ for those who did not do urbanization to one of the cities set. Items of economic infrastructure variable were7 question items, educational facilities were 7 question items, health facilities consisted of 7question items, employment consisted of 5 question items, the security level consisted of 5 question items, and the wage rate consisted of 5 question items. Measurement of all independent variables were grouped by dichotomy, that was score $=1$ if more than $50 \%$ of the total items were considered good, and a score of 0 if less than $50 \%$ of total items considered were not good questions.

Data analysis technique used was the Logistic Regression Model and since the urbanization destination cities were as many as two, then the Logistic Regression Model was used as many as the number of urbanization destination cities. Model 1 is for urbanization to Padang and model 2 is for urbanization to Pekanbaru. 


\section{Results}

To determine the suitability of the model with the existing data, first Hosmer and Lemeshow test was conducted. The results show the Chi Square Value for model 1 was 6.281 with significant level of 0.507 and Chi Square Value for model 2 was 6.113 with significant level of 0.411 . The value of significant level of the two models were higher than $5 \%$ error rate. Therefore, these models are eligible to be used in the next analysis.

The parameter value of each variable can be written in the following equation:

Ln $\left(\frac{P}{1-P}\right)=-1.568+0.831 \mathrm{X}_{1}+0.522 \mathrm{X}_{2}+0.833 \mathrm{X}_{3}+0.195 \mathrm{X}_{4}+0.207 \mathrm{X}_{5}-0.182 \mathrm{X}_{6}$

(Model 1)

In addition, logistic regression equation for model 2 can be written as follows:

$\operatorname{Ln}\left(\frac{P}{1-P}\right)=-0.623+0.803 \mathrm{X}_{1}+0.523 \mathrm{X}_{2}+0.834 \mathrm{X}_{3}+0.004 \mathrm{X}_{4}+0.448 \mathrm{X}_{5}+0.388 \mathrm{X}_{6}$

(Model 2)

Table 1 Results of Logistic Regression Analysis

\begin{tabular}{|c|c|c|c|c|c|c|c|c|c|c|}
\hline & \multicolumn{5}{|c|}{ Model 1} & \multicolumn{5}{|c|}{ Model 2} \\
\hline & B & SE & Wald & Sig. & $\operatorname{Exp}(B)$ & B & SE & Wald & Sig. & $\operatorname{Exp}(B)$ \\
\hline Step 1a X1 & .831 & .374 & 4.929 & .026 & .436 & .803 & 352 & 5.196 & .023 & 2.233 \\
\hline $\mathrm{X} 2$ & .522 & .134 & 15.137 & .000 & 1.685 & .523 & .538 & 942 & .332 & .593 \\
\hline X3 & .833 & .379 & 4.841 & .028 & .435 & .834 & 178 & 4.860 & .036 & 2.302 \\
\hline $\mathrm{X} 4$ & .195 & .025 & 7.880 & .022 & .823 & .004 & .001 & 7.237 & .030 & 1.000 \\
\hline X5 & .207 & .216 & 17.003. & .000 & 1.230 & .448 & .109 & 923 & .337 & 639 \\
\hline X6 & .182 & 1.024 & .031 & .859 & 0.799 & .388 & .093 & 17.333 & .000 & 1.474 \\
\hline $\begin{array}{l}\text { Consta } \\
\text { nt }\end{array}$ & -1.568 & .713 & 4.833 & .028 & .208 & -.623 & .597 & 1.088 & .297 & .536 \\
\hline
\end{tabular}

Economic infrastructure (X1) has a significant effect on the decision of the jobseekers to do urbanization to Padang and Pekanbaru. Furthermore, it can be interpreted that better and more complete economic infrastructure owned by a city will become an attraction for prospective job seekers to do urbanization compared to bad city infrastructure. Cities with good and complete economic infrastructure attract the prospective jobseekers to do urbanization. Empirically, it is proved that the opportunity of doing urbanization to Pekanbaru is relatively higher when compared to Padang as indicated by the value of model 1 Odd Ratio by 0.436 and model 2 by 2.23 . It is factually proved over the last ten years in which the economic infrastructure of Pekanbaru is progressing very rapidly such as the construction of roads, bridges, modern shopping centers, hotels and industries. It is in contrast to the condition of Padang with not much development in the construction of economic infrastructure over the last ten years. Even after the earthquake in 2009 that destroyed the existing economic infrastructure, although it has improved, the condition is still far behind from Pekanbaru. The condition of Padang is worsened by its nickname as the Earthquake and Tsunami Prone City, resulted in a little setback in the investment flow. Economic infrastructure completeness will affect the attractiveness of the city, because a good economic infrastructure will provide a wider access to the citizen to convey their desires socially and economically to get better quality of life (Cobbinah et al: 2015) and (Miao and Wu: 2016).

Educational facility (X2) has a significant effect for prospective jobseekers to take the decision to do urbanization into a city. In this study, it is proved that educational facilities in Padang affects significantly job seekers to take a decision to do urbanization, while for urbanization to Pekanbaru this variable does not have a significant effect. Based on the value of odds ratio, it is proved that 
opportunities for urbanization to Padang with consideration of the facility and a better quality of education is higher when compared to PekanBaru, as indicated by each Odd ratio 1.69 and 0.59 respectively. Padang since the days of pre-independence has been known as the city of education because it has produced quite a lot of the national thinker such as KH. Agus Salim, Sutan Syahril, Hamka and Agus Salim and until now the impression is still attached to the people's mind. Consideration of facilities and a good quality of education is a rational consideration for prospective job seekers to do urbanization because they will send their children to school when they have children in the future. The educational social facilities are the most basic facilities owned by the city and as a pull factor for urbanization as stated by Cobbinah et al (2015). On the other side, education is also a part of the social capital which affects the quality of life of the city residents (Buhuaga \& Urdal (2002). The increasing attractiveness of cities for prospective job seekers is in line with growing public awareness for education.

Health facility (X3) owned by Padang and Pekanbaru significantly affects the decision of job seekers to do urbanization as indicated by Wald Test Value of each city by 4.84 and 8.34 with a significant level of 0.28 and 0.36 . However, the opportunities to do urbanization to Pekanbaru tends to be higher compared to Padang as shown by Odd Ratio value of 0.43 and 2.30 respectively. Therefore, one of the considerations for prospective job seekers in making decision to do urbanization to Pekanbaru is the completeness of facilities and better health care. This condition is in fact inseparable with Pekan Baru municipality policies in improving the quality and availability of the infrastructure needed by its residents, especially during the last 10 years or during the era of regional autonomy. Through the expansion of the authority granted by the central government for the local government, Pekanbaru municipality has been employing many deregulations in the issuance of permit to establishment a hospital with relatively easy requirements. The positive impact is the emerging and with a considerable amount of service of international private hospital. It aims to provide access high quality health services widely to the community and also as one of the strategies of the municipality to reduce the tendency to seek abroad hospital treatments such as to Malacca, Penang and Singapore for the last 10 years that is increasing. This is as a result of the lack of good quality health care services in Indonesia. Health care is one of the basic services owned by a city in order to improve the quality of people's lives. Along with the increasing level of education, socioeconomic then the demand for health quality also tends to increase as argued by Miao and $\mathrm{Wu}(2016)$. The availability of good health facilities will become a pull factor for job seekers to do urbanization to a city along with the high level of public awareness on health.

Employment variable $(\mathrm{X} 4)$ shows significant effect on the decision to do urbanization either to Kota Padang and Pekanbaru as indicated by the value of Wald Test by 7.88 and 7.24 respectively with significant level at 0.02 and 0.03 . The availability of employment will highly determine the prospective jobseekers' decision to do urbanization to any city since the motive of urbanization for jobseekers is to earn income through work. The increasing availability of employment will be appealing for job seekers moving into a city so that they can increase their lives into a better one because of the socio-economic urbanization phenomenon (Liddle \& Lung, 2014). As an economic phenomenon, the consideration of the job seekers to do urbanization is to improve their social and economic status reflected by the jobs and income they earn. Further, opportunities to do urbanization to Pekanbaru are relatively higher when compared to Padang as indicated by odds ratio 0,82 and 1.00 . Therefore, the decision to do urbanization will be largely determined by the availability of jobs regardless which city they move into. However, when determining the decision, the job seekers tend to choose the city that provides more jobs so that they obtain higher employment opportunities. Higher job opportunity is a consideration for jobseekers to do urbanization and then choose what sector that can maximize the results as they expect (Todaro, 2012). On the other hand, the availability of employment cannot be separated from the various economic activities and the implementation of development which contribute to the urbanization (Allen, 2002). 
Security level (X5) of a city significantly affects the decision of job seekers to do urbanization. A safe and convenient city will become a pull factor for job seekers to do urbanization. Padang is a city that has a high attraction for job seekers because of its security factor, as indicated by the Wald test value of 17.00 with significant level of 0.00 , in contrast to Pekanbaru. The high level of security leads to higher opportunity for the jobseekers to do urbanization to Padang than to Pekanbaru as indicated by the value of each Odd ratio of 1.23 and 0.64. It is factually proved in 2015 that West Sumatra province is not included in the ten provinces with the highest crime risk in Indonesia. The safe city condition will be an attraction for job seekers to perform economic activities without worrying the security and order disruption, although conversely the high urbanization flow can also lead to violence and inconvenience Burhaug \& Urdal (2013).

The wage rate (X6) has very significant effects on the decision of jobseeker to do urbanization to Pekanbaru,yet in significantly to Padang. Based on Odd value ratio, it is known that opportunities of the job seekers to do urbanization to Pekanbaru tend to be higher compared to Padang, with Odd value ratio of each city 0,80 and 1.47 . The results of the analysis prove that the attraction of Pekanbaru for job seekers to do urbanization tends to be higher, it is supported by the high wage rate compared to Padang. Based on Government Regulation No. 78/2015 regarding: Wage formula in the Indonesia, Riau Province has Provincial Minimum Wage (UMP) of IDR2,266,722, - while for West Sumatra Province is IDR. 1,949,284, -. This condition is in fact supported by higher investment flows into Riau province especially to Pekan Baru which promote the development of palm and rubber plantations, agricultural product processing industry, trade sector and other services. The high analog employment opportunity with a high demand for labor will increase the wage rate to rise. The high level of wages in a city cannot be denied tobe an attraction for workers from the surrounding area to do urbanization with relatively low wages (Harris-Todaro: 2012), (Lewis in Todaro: 2012) and Suckall et al, 2015)

Both cities have different characteristics and attractions that can be developed into a uniqueness and strength in urban development planning in the future. Padang's attraction for the jobseekers lies on the five strengths including economic infrastructure, education facilities, health facilities, employment and security. While the pull factors of urbanization to Pekanbaru are these four: economic infrastructure, health facilities, employment and wage rate. The variables with same attraction are: economic infrastructure, education, health, employment. Both cities have the uniqueness in the opportunities / possibilities for job seekers to do urbanization. Opportunities for job seekers to do urbanization to Pekanbaru tend to be higher compared to Padang. This decision is supported by the economic infrastructure in Pekanbaru which is physically better than Padang. Opportunity for job seekers to do urbanization is due to the consideration with tendency on higher education facilities than Padang. This decision is because Padang has been known since along time as a city of education and has produced a lot of national figures, at the moment Padang is ranked higher on national examination than Pekanbaru. Health facilities variable becomes consideration for job seekers in doing urbanization and the opportunities of urbanization to Pekanbaru have a higher chance compared to Padang; because it is supported by a number of hospitals in PekanBaru with international standard services. Employment variable provides higher opportunity for job seekers to Pekanbaru than to Padang because of many available employment opportunities along with the increasing investment flows into this region in various sectors of the economy.

Two variables which become identifier for each city as urbanization destination are: security level and wage rate. Job seekers tend to do urbanization to Padang with a high opportunity than Pekan Baru with a high security level as indicated by the low number criminality in this city, it is also because there are few industries and pollution. It is in contrast to Pekanbaruwith the top attraction on high wage rate than Padang. The high wage rates in accordance with the increasing flow of investment in various economic sectors, this leads to an increase in the demand for labor which later on increasing higher wage rate. The results of the study prove that the consideration for urbanization is not only affected by the economics phenomenon such as complete economic infrastructure, 
plentiful employment are and high wage rate but also there is still non-economic variables considered by the prospective job seekers such as education facilities, health and security level as the social variables Miao and $\mathrm{Wu}(2016)$.

\section{Conclusions}

The study concludes that the six variables supposed to affect the decision of jobseekers to do urbanization have different effects on Padang and Pekanbaru. Economic infrastructure significantly affects the decision of jobseekers to do urbanization either to Padang or Pekan Baru. However, the opportunity of prospective jobseeker to do urbanization to Pekanbaru tends to be higher than to Padang, this decision is supported by the availability and completeness of the economic infrastructure in Pekan Baru which tends to be better and more comprehensive than Padang. Education facilities have significant effects on the decision of prospective job seekers to do urbanization to Padang and the opportunities of job seekers to do urbanization to Padang tends to be higher because of the facilities and the quality of education Padang tend to be better than Pekan Baru. Additionally, the consideration of the health facilities on the decision to do urbanization either to Padang or Pekanbaru, both have a significant effect. Meanwhile, the tendencies of job seekers in choosing urbanization to Pekanbaru is higher because Pekanbaru has better and more complete health care services with international standard. Employment variable is taken into consideration for prospective jobseekers in making decision to do the urbanization, but the opportunity of prospective job seekers to do urbanization to Pekanbaru tends to be higher. This is supported by the availability of jobs in Pekanbaru which tendsto have more diverse options of occupations. Therefore, the opportunity of getting a job in Pekanbaru will tend to be higher, along with the increasing investment flow into this area over the last ten years.

Two variables which distinguish between Padang and Pekanbaru includes: security level and wage rate. Prospective job seekers tend to decide to do urbanization to Padang with security considerations, while to Pekanbaru with wage rate consideration. Padang has a more conducive security level asindicated by the low crime rate, while Pekan Baru has a higher wage rate along with the development of investment in various economic sectors. Economically, the development of the industrial sector is analogous to the increase in the demand for labor and also will drive the wage rate higher.

Based on the result of the research, it can be formulated several suggestions to the municipality/citygovernment in order to strengthen the policies in accordance with the characteristics of each city.

1. To the government of Padang is advised to focus more on improving education facilities and increasing order and security level as the main attraction of Padang. In other side, it should maintain the availabilityof good economic infrastructure, health services, and increasing employment opportunities through increasing investment in accordance with the potential of the city.

2. To the Government of Pekanbaru we suggestto focus more on improving the economic infrastructure towardsa better direction, health facilities, employment opportunities and wage rate through increasing investment in accordance with the city potential.

\section{References}

Allen, A. (2002). Urban Sustainability under Threat: The Restructuring of the Fishing Industry in Mar del Plate, Argentina. In D. Westendorff \& D. Eade (Eds.), Development and cities. Geneva and Oxford: UNRISD and Oxfam.

Arouri, M., Youssef, AB., and Nguyen, C.(2017). Does urbanization reduce rural poverty? evidence from vietnam. economic modeling, 60(2017) 253-270 journal homepage: www.elsevier.com/locateleconmod 
Bao, C., and Fang, C. (2012). Water resources flows related to urbanization in china: Challenges and perspectives for water management and urban development. Water Resources Management, 26(2).

Behera, S.R., Dash., and D.P.(2017). The effect of urbanization, energy consumption, and foreign direct investment on the carbon dioxide emission in the SSEA (South and Southeast Asian) region. Renewable and Sustainable Energy Reviews 70 (2017) 96-106. journal homepage: www.elsevier.com/locate/rser

Buhaug, $\mathrm{H}$ and Urdal, H.(2013). An urbanization bomb? population growth and social disorder in cities. Global Environmental Change 23 (2013) 1-10. www.elsevier.com/locate/gloenvcha

Cobbinah, P.B., Erdiaw-Kwasie, M.O., and Amoateng, P.(2015). Africa's urbanisation: implications for sustainable development. Cities. Journal homepage: www.elsevier.com/locate/cities.

Curtis, K., Fussell, E., and Dewaard, J.(2015).Recovery migration after hurricanes Katrina and Rita: spatial concentration and intensification in the migration system. Demography, 1e25.

Hariyono, P.(2007).Sociology city for architects. Jakarta:PT Bumi Aksara Publisher.(http://wahyusriyantopendidikanekonomi.blogspot.com/) (diunduh tanggal 11/09/2014). http://www.goriau.com/berita/gonews-group/pekanbaru-kota-investasi-terbaik-diindonesia.html\#sthash.my7Hcxoc.dpuf

Henderson, J.V.,Storeygard, A., and Deichmann,U.(2016).Has climate change driven urbanization in Africa?.Journal of Development Economics.www.elsevier.com/locate/jdeveco.

Jhingan, M.L. (2003). The economics of development and planning. New Delhi : Vicas Publishing.

Lian. H.,L, R.P. (2014). Interpreting Institutional Fit: Urbanization, Development, and China's "Land-Lost. World Development Vol. 61, pp. 1-10, 2014 _ 2014 Elsevier Ltd. All rights reserved.

Liddle,B and Lung. S. (2014). Might electricity consumption cause urbanization instead? Evidence from heterogeneous panel long-run causality tests. Global Environmental Change 24 (2014) 42-51

Miao, J and Wu.X. (2016). Urbanization, socioeconomic status and health disparity in china. Health \& Place 42 (2016) 87-95. Journal homepage: www.elsevier.com/locate/healthplace.

McGranahan, G., Mitlin, D., Satterthwaite, D., Tacoli, D., \& Turok, I. (2009). Africa's urban transition and the role of regional collaboration. International Institute for Environment and Development (IIED) (pp. 1-58).

Suckall, N, et al. (2015). Using a migration systems approach to understand the link between climate change and urbanisation in malawi, Applied Geography 63 (2015) 244-252.

Shryock, H.S. and Siegel. J.S. (1976). The Methods and Materials of Demography. New York: Academic Press.

The Central Bureau of Statistics. 2012-2015.West Sumatra in Figures. Padang: The Central Bureau of Statistics.

Todaro, M, P, and Stephen C. S.(2012).Economic Development, 11th Edition.United Kingdom : Pearson Education Limited.

Turok and Mc Granahan, (2013). Urbanisation and economic growth: The arguments and evidence for Africa and Asia. Environment \& Urbanisation, 25(2),465-482.

Wongboonsin, K and Piyachart, P. (2016). Searching for emperical linkages between demografic structure and economic growth. Juornal of Economic Modeling, 60 (17). 371. 